\title{
Meal frequency and energy balance
}

\author{
BY FRANCE BELLISLE ${ }^{1}$, REGINA MCDEVITT ${ }^{2}$ AND ANDREW M. PRENTICE ${ }^{2}$ \\ ${ }^{1}$ INSERM U341, Hotel Dieu de Paris, 1 place du Parvis Notre-Dame, 75181 Paris Cedex 04, France \\ ${ }^{2}$ MRC Dunn Clinical Nutrition Centre, Hills Road, Cambridge CB2 $2 D H$
}

Several epidemiological studies have observed an inverse relationship between people's habitual frequency of eating and body weight, leading to the suggestion that a 'nibbling' meal pattern may help in the avoidance of obesity. A review of all pertinent studies shows that, although many fail to find any significant relationship, the relationship is consistently inverse in those that do observe a relationship. However, this finding is highly vulnerable to the probable confounding effects of post hoc changes in dietary patterns as a consequence of weight gain and to dietary under-reporting which undoubtedly invalidates some of the studies. We conclude that the epidemiological evidence is at best very weak, and almost certainly represents an artefact. $A$ detailed review of the possible mechanistic explanations for a metabolic advantage of nibbling meal patterns failed to reveal significant benefits in respect of energy expenditure. Although some short-term studies suggest that the thermic effect of feeding is higher when an isoenergetic test load is divided into multiple small meals, other studies refute this, and most are neutral. More importantly, studies using whole-body calorimetry and doubly-labelled water to assess total $24 \mathrm{~h}$ energy expenditure find no difference between nibbling and gorging. Finally, with the exception of a single study, there is no evidence that weight loss on hypoenergetic regimens is altered by meal frequency. We conclude that any effects of meal pattern on the regulation of body weight are likely to be mediated through effects on the food intake side of the energy balance equation.

Meal frequency: Nibbling: Gorging: Energy balance

The present paper reviews the epidemiological studies relating meal frequency to body weight, and attempts to integrate these with the results of physiological investigations on meal frequency and energy metabolism. The paper will focus exclusively on human subjects because, although there is a considerable literature describing the metabolic effects of differing meal patterns in experimental animals (Fabry \& Tepperman, 1970; Adams \& Morgan, 1981; Bellisle, 1995), there are important ecological differences between the natural feeding patterns of species, and because the human experimental data are adequate to answer the key questions relating to the efficiency of energy utilization in this context.

\section{EPIDEMIOLOGICAL ASSOCIATIONS BETWEEN HABITUAL MEAL FREQUENCY AND BODY WEIGHT}

The extensive work of Fabry and co-workers (Fabry et al. 1964, 1966; Hejda \& Fabry, 1964) was the first to demonstrate strong and reproducible inverse relationships between habitual meal frequency and body weight in human subjects. Results from their first large sample study involving 379 Czechoslovakian men aged 60-64 years (Fabry et al. 1964) are illustrated in Fig. 1. Both the proportion of overweight subjects and mean skinfold thicknesses were significantly inversely related to meal frequency. Similar trends were observed in a smaller sample of eighty-nine men aged 30-50 years (Hejda \& Fabry, 1964). 

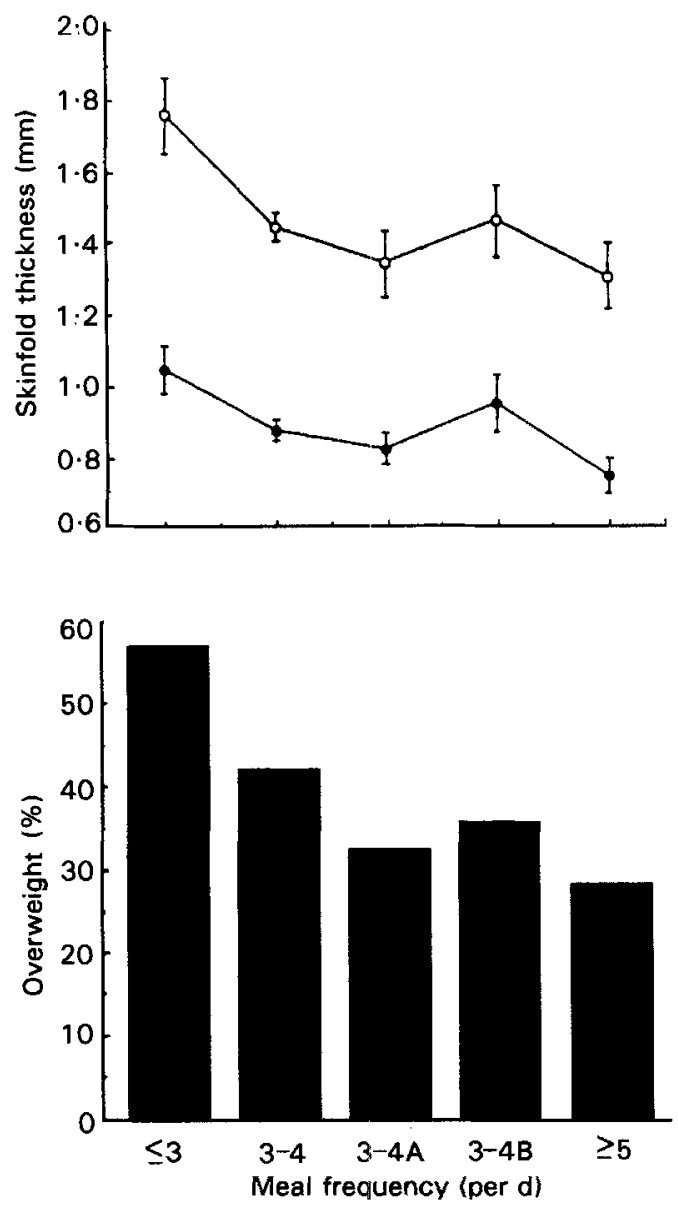

Fig. 1. Relationship between habitual meal frequency and body fatness in 379 Czechoslovakian men aged 60-64 years. (O), Triceps skinfold thickness; $(O)$, subscapular skinfold thickness; $A$, additional snacks between meals; $B$, additional snacks at bedtime. Values are means with their standard errors represented by vertical bars. (Data from Fabry et al. 1964.)

Fabry et al. (1966) also performed an intervention study in which two schools for 616-year-old children were selected for comparison of a three meal $v$. seven meal daily regimen, whilst a third school remained on its normal five meals daily pattern (total $n 226$ children). Average energy intakes did not differ significantly between schools. The results of this 1-year intervention were assessed using an 'index of proportionality' which summarized changes in weight relative to height growth (high index of proportionality represents greater relative weight gain). For older children (10-16 years) there was a higher proportion of subjects with an elevated index of proportionality in the school with three meals daily compared with the other two schools $(P<0.05$ for boys and $P<0.001$ for girls). Changes in triceps, subscapular and abdominal skinfolds mirrored the changes in proportionality index. For younger children there were no significant differences.

Subsequent studies by other workers are summarized in Table 1 . Some report nonsignificant effects, but where significant effects are reported they all support the Fabry et al. 
Table 1. Summary of epidemiological studies investigating the relationship between meal frequency and measures of body mass or body fatness

\begin{tabular}{|c|c|c|c|c|c|c|}
\hline \multirow[t]{2}{*}{ Reference } & \multirow[t]{2}{*}{ Sample size } & \multicolumn{2}{|c|}{ Subjects } & \multirow{2}{*}{$\begin{array}{l}\text { Meal frequency } \\
\text { (daily) }\end{array}$} & \multirow[t]{2}{*}{ Outcome measures } & \multirow{2}{*}{$\begin{array}{l}\text { Statistical } \\
\text { significance }\end{array}$} \\
\hline & & Sex & Age (years) & & & \\
\hline Fabry et al. (1964) & 379 & $\mathbf{M}$ & $60-64$ & $\leq 3-\geq 5$ & $\begin{array}{l}\text { Overweight } \\
\text { SFT }\end{array}$ & $\begin{array}{l}-, P \leq 0.01 \\
-, P \leq 0.05\end{array}$ \\
\hline Fabry et al. (1966) & 226 & $M+F$ & $6-16$ & $3,5+7$ & $\begin{array}{l}\text { Body wt } \\
\text { SFT }\end{array}$ & $\begin{array}{l}-, \text { Significant }{ }^{\dagger} \\
-, \text { Significant }{ }^{\dagger}\end{array}$ \\
\hline Metzner et al. (1977) & 2028 & $\mathbf{M}+\mathbf{F}$ & $35-69$ & $1-\geq 8$ & Adiposity Index $\ddagger$ &,$- P \leq 0.01$ \\
\hline Charzewska et al. (1981) & 886 & $\mathbf{M}$ & $40-59$ & $2,3-4,5-7$ & $\begin{array}{l}\text { Percentage body } \\
\text { fat } \$ \\
\text { BMI }\end{array}$ & $\begin{array}{l}-, P<0.05 \\
-, P<0.05\end{array}$ \\
\hline Dreon et al. (1988) & 155 & $\mathbf{M}$ & $39-50$ & $1-7$ & $\begin{array}{l}\text { Percentage body } \\
\text { fat } \S \\
\text { BMI }\end{array}$ & $\begin{array}{l}\text { NS } \\
\text { NS }\end{array}$ \\
\hline Edelstein et al. (1992) & 2034 & $M+F$ & $50-89$ & $1-2,3, \geq 4$ & $\begin{array}{l}\text { BMI } \\
\text { Waist : hip }\end{array}$ & $\begin{array}{l}\text { NS } \\
-, P \leq 0.01\end{array}$ \\
\hline Kant (1995) & 7147 & $M+F$ & $35-84$ & $\begin{array}{l}\text { Follow-up } \\
\leq 2-\geq 7\end{array}$ & $\begin{array}{l}\text { Wt change } \\
\text { Baseline BMI } \\
\text { TSF } \\
\text { SSF } \\
\text { Wt change } \\
\text { Baseline BMI } \\
\text { TSF } \\
\text { SSF }\end{array}$ & $\begin{array}{l}-, P \leq 0.05 \\
-, P \leq 0.05 \\
-, P \leq 0.05 \\
-, P \leq 0.05 \\
\text { NS } \\
\text { NS } \\
\text { NS } \\
\text { NS }\end{array}$ \\
\hline Summerbell et al. (1996) & 220 & $\mathbf{M}+\mathbf{F}$ & $\begin{array}{l}\text { Elderly } \\
\text { Working age } \\
\text { Middle-aged } \\
\text { Adolescents }\end{array}$ & $1-3,4-6$ & $\begin{array}{l}\text { BMI } \\
\text { BMI } \\
\text { BMI } \\
\text { BMI }\end{array}$ & $\begin{array}{l}\text { NS } \\
\text { NS } \\
\text { NS } \\
-, P \leq 0.05\end{array}$ \\
\hline
\end{tabular}

SFT, skinfold thickness; TSF, triceps skinfold; SSF, subscapular skinfold; - , negative relationship; $M$, male; F, female.

$* 10 \%$ overweight

$\uparrow$ Actual level of significance not given.

$\ddagger$ Adiposity index combines four different skinfold measures and BMI.

$\$$ Measured from underwater weighing.

II Narrow range of subject type, all obese sedentary males.

I Follow-up study 10 years later used different methodologies of meal frequency estimation (see pp. S60-S61)

(1964) initial demonstration of lower body weight and adiposity in nibblers compared with gorgers. (In common with other authors we have adopted the terms 'nibbling' and 'gorging' to describe the two ends of whatever spectrum of meal patterns is covered in each study.) Fig. 2 illustrates the adiposity index for 948 men and 1080 women in the Tecumseh Community Health Study (Metzner et al. 1977). Apart from the very small number of subjects consuming only one meal daily (two men and four women; combined in the category $\leq$ two meals in Fig. 2) there was a highly significant inverse trend for both sexes ( $P<0.008$ for men and $P<0.001$ for women).

Charzewska et al. (1981) studied the relationship between meal frequency and overweight in 886 Polish men aged $40-59$ years. BMI averaged $27.8,26.8$ and $26.5 \mathrm{~kg} / \mathrm{m}^{2}$ in men consuming two, three to four and five to seven meals daily respectively $(P<0.05$ for trend). A similar relationship existed when BMI was analysed according to the interval 


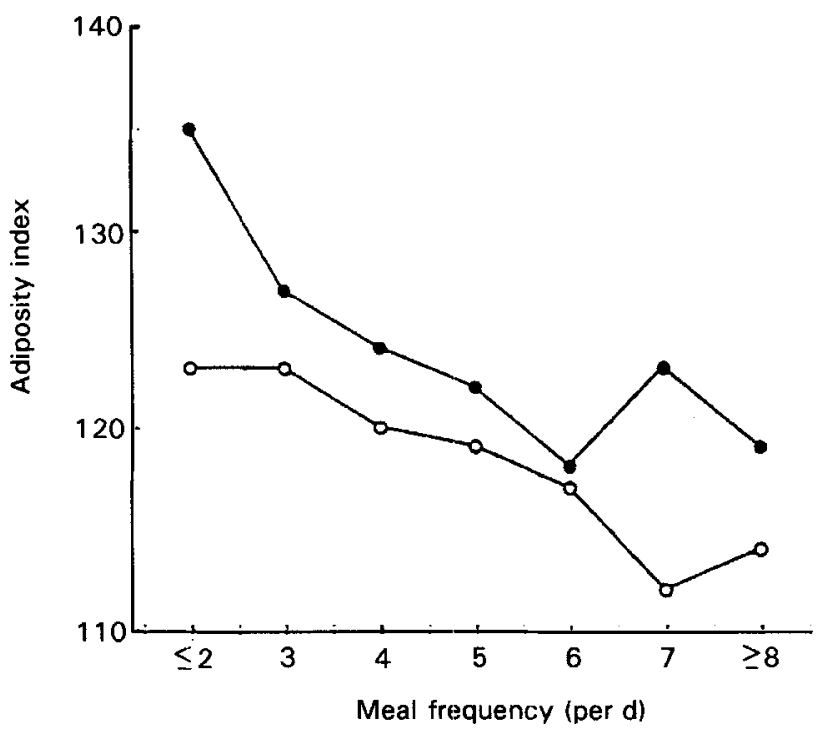

Fig. 2. Relationship between habitual meal frequency and body fatness in adult men and women in the Tecumseh Community Health Study. Adiposity index combines BMI and skinfolds and describes adiposity relative to the population median. Data from 948 men (O) and 1080 women (O). (Redrawn from Metzner et al. 1977.)

between meals. Another Polish study comparing dietary patterns in groups of 100 obese and fifty normal-weight women also found that the obese tended to consume fewer meals daily $(P<0.05$; Kulesza, 1980).

The NHANES I Epidemiologic Follow-Up Study is more difficult to interpret. It obtained measures of meal frequency at baseline (1971-5) and at follow-up (1982) and related these to BMI at each time period and to weight gain between baseline and followup (Kant, 1995). The estimates of frequency at baseline were obtained from $24 \mathrm{~h}$ recall of actual times of eating, and at follow-up from two questions concerning usual meal frequency and usual snacking patterns. At baseline, associations between eating frequency and BMI or skinfolds were weak and inconsistent for men, but strong for women and in the inverse direction, thus supporting the work of Fabry et al. $(1964,1966)$ and Hejda \& Fabry (1964). Subsequent weight changes were also significantly related to eating frequency at baseline, but in an unpredictable manner. In women the highest gain was in those consuming two or fewer meals daily, but in men this category showed the lowest gain. In women there was a steady increase in weight gain over the other meal-frequency categories, and a similar tendency in men. However, all these relationships became nonsignificant when adjusted for possible confounders in multivariate regression analysis (physical activity, smoking status, alcohol intake and morbidity). The interpretation of this data-set is further complicated by the fact that meal frequency measured at follow-up was not significantly related to measures of fatness or weight gain in either sex.

Finally, a recent study of the eating habits of lean and obese Swedish men found a small difference in intake occasions (meals and snacks combined, 5.6 v. 5.3 daily; $P<0.02$ ), again in support of the contention of Fabry et al. $(1964,1966)$, but the significance disappeared after elimination of under-reporters $(5.3$ v. 5.9 daily; NS; Anderson \& Rossner, 1996). 
Although the relationships between feeding frequency and body weight look quite persuasive in Figs. 1 and 2, in many of the epidemiological studies there has been an absence of critical assessment of some key factors which hamper interpretation. The first of these relates to the reliability of classification of subjects' meal frequency. Kant (1995) found a very low reproducibility of the frequency estimates between baseline and followup (Kendall's coefficient of concordance $0 \cdot 1$ ). This is likely to be particularly critical in studies such as that of Kant (1995) which use only a single day to estimate habitual frequency, but to some extent is the least of the methodological problems since it will tend to obscure actual relationships (Type II error) rather than generate spurious relationships.

The more important potential errors relate first to the issue of dietary under-reporting by overweight people, and second to the possibility of reverse causality. Dietary underreporting by obese, post-obese, overweight and diet-restrained subjects has now been shown to be one of the most robust biopsychological phenomena ever described (Prentice et al. 1986; Lichtman et al. 1992; Black et al. 1993), and there is evidence that snacks are especially prone to under-reporting, which would impinge strongly on the validity of mealfrequency estimates (Livingstone et al. 1990; Heitmann \& Lissner 1995; Poppitt et al. 1995). The importance of this phenomenon is illustrated in Fig. 3 using the Kant (1995) data for women. Fig. 3(a) shows the apparent strong inverse relationship between meal frequency and mean BMI and skinfold thicknesses. Fig. 3(b) shows the reported energy intakes and compares them with the population predicted minimal energy requirements using the Goldberg et al. (1991) cut-offs derived from physiological first principles. It is apparent that most of the estimates of energy intake are impossibly low, indicating massive under-reporting, especially in view of the fact that the cut-offs are set at a very conservative value of only $1.4 \times$ BMR. The strong inverse relationship between apparent energy intake and $\mathrm{BMI}$ is also quite impossible and cannot be resolved (as implied by the original authors) by invoking differences in the thermic effect of feeding between nibblers and gorgers (see p. S66). Unreliable dietary data, in which low recorded feed frequencies are highly suggestive of non-reporting of certain eating occasions, are therefore the only possible explanation of the apparent paradox and represent a major issue when trying to detect possible effects of meal frequency on body weight.

The issue of reverse causality is equally important. This refers to the likelihood that people omit meals (particularly breakfast) when they become overweight in an attempt to lose weight or to prevent further gain (Summerbell et al. 1996). Clearly these post hoc alterations in diet pattern would greatly confound data interpretation and would tend to create the inverse relationships observed in some of the studies in Table 1 without implying any causal linkage between meal frequency and changes in body weight.

Summerbell et al. (1996) have addressed these potential errors both in criticising the literature and in a fresh analysis of $7 \mathrm{~d}$ weighed-diet records from 220 subjects covering a range of age-groups. They observed that the inverse relationship between meal frequency and BMI which existed in first-pass analysis disappeared after exclusion of dietary underreporters. This was true for all age-groups except adolescents where it remained marginally significant. However, subsequent analysis has shown that the removal of dieting boys and weight-conscious girls eliminates any association between BMI and meal frequency even in adolescents ( $\mathrm{H}$. Crawley and $\mathrm{C}$. Summerbell, personal communication).

Summerbell et al. (1996) have concluded that the combination of under-reporting and missing meals by overweight people help to resolve the contradictory results of previous studies, and the apparent contradiction between epidemiological data and the experimental data described later (p. S66). We support these cautionary conclusions. These comments, however, refer to cross-sectional epidemiological studies and do not necessarily invalidate 

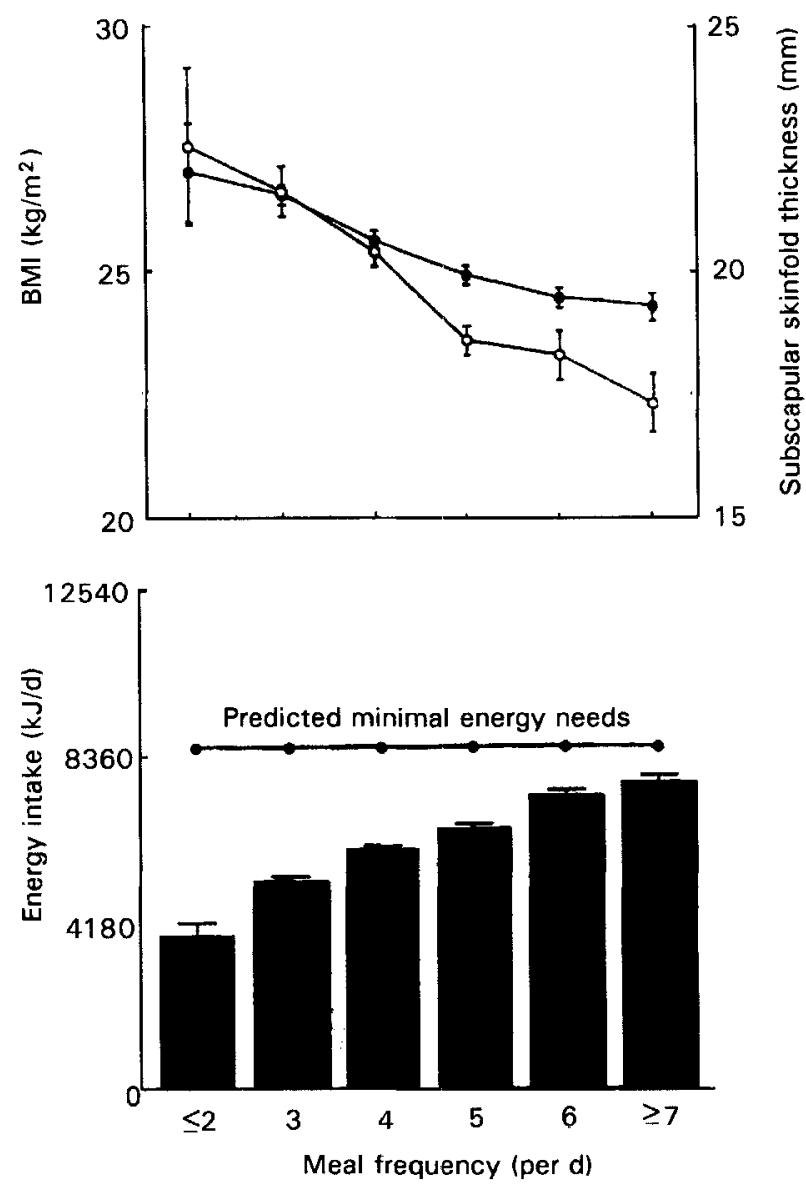

Fig. 3. Measures of adiposity and reported energy intake in the NHANES I Epidemiologic Follow-Up Study. (O), BMI; (O), subscapular skinfold thickness. Data for women only ( $\boldsymbol{n}$ 4567). Values are means with their standard errors represented by vertical bars. Predicted minimal energy needs estimated as $1.4 \times$ predicted BMR (Goldberg et al. 1991). (Data from Kant, 1995.)

the Fabry et al. (1966) intervention studies in schoolchildren. There may be quite different effects of meal frequency in growing and adult animals. This would be consonant with animal literature indicating greater feed conversion efficiency with increased frequency of feeding.

\section{STUDIES ON THE EFFECT OF MEAL FREQUENCY ON WEIGHT LOSS DURING ENERGY RESTRICTION}

Most studies relating to the energetic effects of differing meal frequencies cite the work of Debry et al. (1973) who observed a much better weight loss in dieting subjects on a seven meals daily regimen compared with three meals daily $(142 v .78 \mathrm{~g} / \mathrm{d})$. However, as shown in Table 2, six other published studies which have addressed the same issue found no significant effect of meal frequency, and even the small non-significant trends are in 
Table 2. Summary of studies comparing weight loss on energy restricted nibbling v. gorging regimens

\begin{tabular}{|c|c|c|c|c|c|}
\hline Reference & Subjects & $\begin{array}{l}\text { Weight-loss } \\
\text { regimen }\end{array}$ & $\begin{array}{c}\text { Meal pattern } \\
\text { (no. of meals daily) }\end{array}$ & Results & $\begin{array}{l}\text { Statistical } \\
\text { significance }\end{array}$ \\
\hline $\begin{array}{l}\text { Bortz et al. } \\
\quad(1966)\end{array}$ & $\begin{array}{l}\text { Six women: } \\
\text { 19-56 years } \\
\text { Obese }\end{array}$ & $\begin{array}{c}2.5 \mathrm{MJ} / \mathrm{d} \text { for } 60 \mathrm{~d} \\
(20 \mathrm{~d} \text { on each } \\
\text { meal pattern })\end{array}$ & $\begin{array}{l}\text { Three } \\
\text { One } \\
\text { Nine }\end{array}$ & $\begin{array}{l}\text { Not listed* } \\
-0.23 \mathrm{~kg} / \mathrm{d} \\
-0.24 \mathrm{~kg} / \mathrm{d}\end{array}$ & NS \\
\hline $\begin{array}{l}\text { Finkelstein \& } \\
\text { Fryer (1971) }\end{array}$ & $\begin{array}{l}\text { Eight women } \dagger \text { : } \\
20-22 \text { years } \\
\text { BMI } 27 \mathrm{~kg} / \mathrm{m}^{2}\end{array}$ & $\begin{array}{l}7 \cdot 1 \mathrm{MJ} / \mathrm{d} \text { for } 30 \mathrm{~d} \\
\text { followed by } \\
5 \cdot 9 \mathrm{MJ} / \mathrm{d} \\
\text { for } 30 \mathrm{~d}\end{array}$ & $\begin{array}{l}\text { Three } \\
\text { Six }\end{array}$ & $\begin{array}{l}-6 \cdot 1 \mathrm{~kg} \\
-5 \cdot 5 \mathrm{~kg}\end{array}$ & NS \\
\hline $\begin{array}{l}\text { Young et al. } \\
\qquad(1971)\end{array}$ & $\begin{array}{l}\text { Eleven men: } \\
20-25 \text { years } \\
\text { BMI } 34 \mathrm{~kg} / \mathrm{m}^{2}\end{array}$ & $\begin{array}{r}7.5 \mathrm{MJ} / \mathrm{d} \text { for } \\
14 \text { weeks } \ddagger\end{array}$ & $\begin{array}{l}\text { One, three } \\
\text { and six }\end{array}$ & $\begin{array}{l}\text { Frequency effect } \\
\text { (greater } v \text {. lesser) } \\
-0.32 \mathrm{~kg} \mathrm{BW} \\
-0.12 \mathrm{~kg} \mathrm{FM}\end{array}$ & $\begin{array}{l}\text { NS } \\
\text { NS }\end{array}$ \\
\hline $\begin{array}{l}\text { Debry et al. } \\
\quad(1973)\end{array}$ & $\begin{array}{l}\text { Eight men, } \\
\text { twenty-four women: } \\
16-65 \text { years } \\
120-220 \% \text { IBW }\end{array}$ & $\begin{array}{l}5.0-7.5 \mathrm{MJ} / \mathrm{d} \S \\
42 \% \text { energy } \\
\text { from } \\
\text { carbohydrate }\end{array}$ & $\begin{array}{l}\text { Three } \\
\text { Seven }\end{array}$ & $-78 \mathrm{~g} / \mathrm{d}$ & $\begin{array}{l}P<0.025 \\
\mathrm{~N}>\mathrm{G}\end{array}$ \\
\hline $\begin{array}{c}\text { Debry et al. } \\
\quad(1973)\end{array}$ & $\begin{array}{l}\text { Eight men, } \\
\text { twenty-eight women: } \\
16-65 \text { years } \\
120-220 \% \text { IBW }\end{array}$ & $\begin{array}{l}5.0-7.5 \mathrm{MJ} / \mathrm{d} \S \\
16 \% \text { energy } \\
\text { from } \\
\text { carbohydrate }\end{array}$ & $\begin{array}{l}\text { Three } \| \\
\text { Seven } \\
\text { Seven } \\
\text { Three }\end{array}$ & $\begin{array}{l}\text { Rp } 0.238 \\
\operatorname{Rp} 0.220 \\
\operatorname{Rp} 0.461 \\
\operatorname{Rp} 0.188\end{array}$ & $\begin{array}{l}\mathrm{NS} \\
P<0.025 \\
\mathrm{~N}>\mathrm{G}\end{array}$ \\
\hline $\begin{array}{l}\text { Garrow et al. } \\
\text { (1981) }\end{array}$ & $\begin{array}{l}\text { Fourteen women: } \\
\text { 18-56 years } \\
\text { BMI } 38 \mathrm{~kg} / \mathrm{m}^{2}\end{array}$ & $\begin{array}{r}3.4 \mathrm{MJ} / \mathrm{d} \text { for } \\
3 \text { weeks } \emptyset\end{array}$ & $\begin{array}{l}\text { One } \\
\text { Five }\end{array}$ & $\begin{array}{l}-255 \text { (SE 29) g/d } \\
-224(\text { SE 20) } \mathrm{g} / \mathrm{d}\end{array}$ & NS \\
\hline $\begin{array}{l}\text { Verboeket-van de } \\
\text { Venne \& } \\
\text { Westerterp } \\
\text { (1993) }\end{array}$ & $\begin{array}{l}\text { Fourteen women**: } \\
20-58 \text { years } \\
\text { BMI } 30 \mathrm{~kg} / \mathrm{m}^{2}\end{array}$ & $\begin{array}{c}4.2 \mathrm{MJ} / \mathrm{d} \text { for } \\
4 \text { weeks }\end{array}$ & $\begin{array}{l}\text { Twotł } \\
\text { Three to five } \\
\text { Two } \\
\text { Three to five } \\
\text { Two } \\
\text { Three to five }\end{array}$ & $\begin{array}{l}-4.1 \mathrm{~kg} \mathrm{BW} \\
-4.7 \mathrm{~kg} \mathrm{BW} \\
-2.3 \mathrm{~kg} \mathrm{FM} \\
-2.7 \mathrm{~kg} \mathrm{FM} \\
-1.8 \mathrm{~kg} \text { FFM } \\
-2.0 \mathrm{~kg} \mathrm{FFM}\end{array}$ & $\begin{array}{l}\text { NS } \\
\text { NS } \\
\text { NS }\end{array}$ \\
\hline
\end{tabular}

N, nibbling; G, gorging; BW, body weight; FM, fat mass; FFM, fat-free mass; IBW, ideal body weight; Rp, change in BW expressed as \% IBW.

* Graphical summaries of each subject's weight curve shows no difference.

+ Four subjects followed each meal pattern.

$\ddagger$ After $14 \mathrm{~d}$ run-in on three meals daily subjects were randomly assigned to one, three or six meals daily for 5 weeks then randomly reassigned to these meal patterns for a further 5 weeks.

$\S$ Adjusted to each subject's 'needs'. Three meal schedule was used for first month of diet, followed by seven-meal schedule for second month.

|| Seventeen subjects had 1 month with three meals followed by 1 month with seven meals; nineteen subjects had order reversed.

T Meal frequency effects were tested for $7 \mathrm{~d}$ each during weeks 2 and 3 in randomized order.

** Seven subjects assigned to each meal pattern.

$\dagger \dagger$ Two meals, 1.7 MJ lunch, 2.5 MJ supper; three to five meals, 1.25 MJ breakfast, $1.25 \mathrm{MJ}$ lunch, $1.7 \mathrm{MJ}$ supper with flexibility to use some lunch or supper as snacks.

differing directions. A number of other studies provide additional, although less direct, evidence of non-significant effects (Cohn \& Allweiss, 1963; Nunes \& Canham, 1963; Swindells et al. 1968; Thomas \& Call, 1973). It seems unlikely that this failure to observe an effect can be ascribed to poor study design since, although the sample sizes are smaller than in the initial Debry et al. (1973) study, the protocols are quite robust and the range of feeding frequencies is large (one to nine meals daily). 
The details of the Debry et al. (1973) study are not precisely described in the publications, and it is unclear whether the same subjects appear in different papers. The meal frequencies were applied in non-random order, and it is not clear how the overall ration was decided, and whether or not this was altered during the trial. Each of these features suggests that the result should be interpreted with caution.

The study by Garrow et al. (1981) was conducted entirely within a strictly controlled metabolic ward in which compliance was probably close to perfect. The results, therefore, directly reflect any possible differences in energy expenditure due to altered meal frequency. The other studies were conducted in a free-living setting and, therefore, provide additional insight into possible differences in compliance to the restricted diets since this would affect weight loss. Clearly there was no detectable advantage in terms of the hard end-points of weight or fat loss. Subjective comments reported by Young et al. (1971) favoured three meals daily. Verboeket-van de Venne \& Westerterp (1993) made actual measurements of compliance through dietary records. Although these are notoriously unreliable in obese subjects, especially when given a prescribed diet, they revealed no apparent difference between energy intake on the nibbling and gorging patterns (4.30 v. $4.28 \mathrm{MJ} / \mathrm{d}$ ). Garrow et al. (1981) reported that in their experience patients who are kept rigidly to a low-energy diet $(3.4 \mathrm{MJ} / \mathrm{d})$ find it more tolerable if it is distributed in many short meals.

Three of the weight-loss studies also investigated the influence of meal frequency on the composition of tissue loss. Young et al. (1971) reported no effect on fat loss. Garrow et al. (1981) reported a significantly lower $N$ loss on the nibbling diet $(1.3 \mathrm{~g} / \mathrm{d})$ than on the gorging diet $(2.1 \mathrm{~g} / \mathrm{d} ; P<0.001)$, although the analysis had to be adjusted for powerful order effects since the different feeding patterns were imposed in the second and third weeks of dieting in different subjects. Verboeket-van de Venne \& Westerterp (1993) reported no differential loss of lean or fat tissue.

We conclude that, in spite of the seemingly impressive results favouring a nibbling regimen recorded by Debry et al. (1973), most studies find that meal pattern has no significant impact on weight loss during intentional energy restriction.

\section{SHORT-TERM STUDIES OF DIET-INDUCED THERMOGENESIS}

It is reasonable to suppose that any differences in energy expenditure between nibbling and gorging meal patterns will be most apparent during the period of postprandial nutrient handling when energy is being used for the absorption, transport, interconversion and storage of substrates. The rate of ingestion and absorption of nutrients might influence their short-term metabolic fate with energetic consequences. For instance, a very large bolus meal with a high carbohydrate content might saturate the maximal rate of glycogen synthesis and force additional disposal via de novo lipogenesis; there is much evidence to support a hyperlipogenic effect of gorging in animal studies (Fabry \& Tepperman, 1970). The 'inefficiency' of glycogen synthesis (approximately $2 \%$ ) is much lower than the inefficiency of lipogenesis (approximately $25 \%$; Flatt, 1985) and, hence, a larger meal might be expected to be associated with a greater heat production. Similarly, a large meal might stimulate a greater proportion of 'facultative' thermogenesis, the component which is mediated (especially by carbohydrate) through activation of the sympathetic nervous system (Jéquier, 1992).

For these reasons, and because most investigators do not possess whole-body calorimeters, there have been a number of short-term studies of the thermic effect of 
feeding (TEF), alternatively referred to as diet-induced thermogenesis. The results of these studies, employing intermittent postprandial measures of energy expenditure by ventilated hood or Douglas bag methods, are summarized in Table 3.

A central problem with short-term studies is the question of whether the postprandial measurements capture the entire area under the thermogenic peak. Many studies of TEF restrict their measurements to about $3 \mathrm{~h}$ duration because it is difficult for subjects to remain completely still for longer periods. However, the thermogenic peak may take much longer to subside, particularly after a very large meal. This may be especially pertinent in studies of nibbling $v$. gorging, and it is noteworthy that the two shortest studies in Table 3 , by Tai et al. (1991) and LeBlanc et al. (1993), have yielded almost exactly opposite findings despite their rather similar investigative protocols. In a slightly longer study, Molnar (1992) corroborates the findings of Tai et al. (1991) (TEF is greater on the gorging regimen), but the difference amounts to only $3.4 \%$ of the ingested energy. The other longer studies recorded no significant differences in TEF (Belko \& Barbieri, 1987; Kinabo \& Durnin, 1990).

We conclude that there is no strong evidence in support of a biologically-significant difference in TEF according to meal patterns. The $24 \mathrm{~h}$ studies discussed later (p. S66) entirely corroborate this summary. Further subsidiary support for this conclusion can be drawn from the observation that extraordinarily large doses of carbohydrate $(500 \mathrm{~g}$ per meal) can be disposed of without recourse to any net lipogenesis (Acheson et al. 1982),

Table 3. Summary of studies comparing thermic effect of feeding on nibbling v. gorging regimens

\begin{tabular}{|c|c|c|c|c|c|c|}
\hline \multirow[t]{2}{*}{ Reference } & \multirow[t]{2}{*}{ Subjects } & \multirow[t]{2}{*}{ Outcome measures } & \multirow[t]{2}{*}{ Meal pattern } & \multicolumn{2}{|c|}{ Results } & \multirow[t]{2}{*}{ Significance } \\
\hline & & & & Mean & SE & \\
\hline $\begin{array}{l}\text { Belko \& Barbieri } \\
\quad(1987)\end{array}$ & $\begin{array}{l}\text { Twelve men: } \\
18-34 \text { years } \\
\text { BMI } 22 \mathrm{~kg} / \mathrm{m}^{2}\end{array}$ & TEF for $10 \mathrm{~h}$ & $\begin{array}{l}\text { Two meals ( } 50 \% \text { need) } \\
\text { Four meals ( } 25 \% \text { need) }\end{array}$ & $\begin{array}{l}43 \cdot 3^{*} \\
43 \cdot 4^{*}\end{array}$ & $\begin{array}{l}4.71 \\
5.0\end{array}$ & NS \\
\hline $\begin{array}{l}\text { Kinabo \& Durnin } \\
\quad(1990)\end{array}$ & $\begin{array}{c}\text { Eighteen women: } \\
18-34 \text { years } \\
\text { BMI } 21 \mathrm{~kg} / \mathrm{m}^{2}\end{array}$ & TEF for $6 \mathrm{~h}$ & $\begin{array}{l}\text { High-fat: } \\
\text { One meal }(5040 \mathrm{~kJ}) \\
\text { Two meals }(2520 \mathrm{~kJ}) \\
\text { Low-fat: } \\
\text { One meal }(5040 \mathrm{~kJ}) \\
\text { Two meals }(2520 \mathrm{~kJ})\end{array}$ & $\begin{array}{l}356 \mathrm{~kJ} \dagger \\
340 \mathrm{~kJ} \dagger \\
377 \mathrm{~kJ} \dagger \\
381 \mathrm{~kJ} \dagger\end{array}$ & $\begin{array}{l}23 \\
16 \\
30 \\
27\end{array}$ & NS \\
\hline Molnar (1992) & $\begin{array}{l}\text { Six boys, five girls: } \\
\text { 12(SD 1) years } \\
\text { Obese }\end{array}$ & TEF for $6 \mathrm{~h}$ & $\begin{array}{l}\text { One meal ( } 30 \% \text { REE) } \\
\text { Three meals ( } 10 \% \text { REE) }\end{array}$ & $\begin{array}{r}11.9 \%+ \\
8.5 \%+\end{array}$ & $\begin{array}{l}1.3 \\
0.7\end{array}$ & $\begin{array}{l}P<0.02 \\
\mathrm{G}>\mathrm{N}\end{array}$ \\
\hline Tai et al. (1991) & $\begin{array}{l}\text { Seven women: } \\
23-30 \text { years } \\
\text { Lean }\end{array}$ & TEF for $5 \mathrm{~h}$ & $\begin{array}{l}\text { One meal }(3138 \mathrm{~kJ}) \\
\text { Six meals }(523 \mathrm{~kJ})\end{array}$ & $\begin{array}{l}241 \mathrm{~kJ} \dagger \\
174 \mathrm{~kJ} \dagger\end{array}$ & $\begin{array}{l}34 \\
25\end{array}$ & $\begin{array}{l}P<0.05 \\
\mathrm{G}>\mathrm{N}\end{array}$ \\
\hline $\begin{array}{l}\text { LeBlanc et al. } \\
\qquad \text { (1993) }\end{array}$ & $\begin{array}{l}\text { Three men, } \\
\text { three women: } \\
21-28 \text { years } \\
\text { BMI } 23 \mathrm{~kg} / \mathrm{m}^{2}\end{array}$ & TEF for $4 h$ & $\begin{array}{l}\text { One meal }(2732 \mathrm{~kJ}) \\
\text { Four meals }(683 \mathrm{~kJ})\end{array}$ & $\begin{array}{l}180 \mathrm{~kJ} \dagger \\
259 \mathrm{~kJ} \dagger\end{array}$ & $\begin{array}{l}16 \\
29\end{array}$ & $\begin{array}{l}P<0.05 \\
\mathrm{~N}>\mathrm{G}\end{array}$ \\
\hline
\end{tabular}

$\mathrm{N}$, nibbling; $\mathrm{G}$, gorging; TEF, thermic effect of food; REE, $24 \mathrm{~h}$ resting energy expenditure.

* Litres $\mathrm{O}_{2}$ above resting levels.

$\dagger \mathrm{kJ}$ above resting levels.

$\ddagger \%$ Energy in meals. 
thus undermining one of the initial arguments in favour of the hypothesis that TEF might differ according to meal pattern.

\section{STUDIES OF TOTAL ENERGY EXPENDITURE}

Irrespective of any possible effects of meal pattern on TEF the key determinant of any ultimate effect on energy balance will be whether nibbling or gorging habits have any impact on total $24 \mathrm{~h}$ energy expenditure. Five studies using $24-48 \mathrm{~h}$ whole-body calorimetry are listed in Table 4; one of these made additional measurements of freeliving energy expenditure over $7 \mathrm{~d}$ periods by doubly-labelled water. In addition to the over-riding advantage of covering the whole $24 \mathrm{~h}$ period, these studies also benefit from generally superior protocols, including dietary adaptation periods before the calorimetry (6-14 $\mathrm{d}$ in all except one study) and good discrimination between the nibbling and gorging meal patterns.

Table 4. Summary of studies comparing total daily energy expenditure on nibbling v. gorging regimens

\begin{tabular}{|c|c|c|c|c|c|c|}
\hline \multirow[t]{2}{*}{ Reference } & \multirow[t]{2}{*}{ Subjects } & \multirow[t]{2}{*}{ Outcome measures } & \multirow[t]{2}{*}{ Meal pattern } & \multicolumn{2}{|c|}{ Results } & \multirow{2}{*}{$\begin{array}{l}\text { Statistical } \\
\text { significance }\end{array}$} \\
\hline & & & & Mean & SE & \\
\hline $\begin{array}{l}\text { Dallosso et al. } \\
\text { (1982) }\end{array}$ & $\begin{array}{l}\text { Eight men: } \\
18-23 \text { years } \\
\text { BMI } 22 \mathrm{~kg} / \mathrm{m}^{2}\end{array}$ & $\begin{array}{l}24 \mathrm{~h} \text { EE* } \\
7-14 \mathrm{~d} \text { adaptation }\end{array}$ & $\begin{array}{l}\text { Two meals }(88 \mathrm{~kJ} / \mathrm{kg} \text { per d) } \\
\text { Six meals }(29 \mathrm{~kJ} / \mathrm{kg} \text { per d) }\end{array}$ & $\begin{array}{l}9759 \\
9639\end{array}$ & $\begin{array}{l}408 \mathrm{~kJ} / \mathrm{d} \\
314\end{array}$ & NS \\
\hline $\begin{array}{l}\text { Wolfram et al. } \\
\text { (1987) }\end{array}$ & $\begin{array}{l}\text { Two men, } \\
\text { six women: } \\
20-23 \text { years } \\
\text { BMI } 23 \mathrm{~kg} / \mathrm{m}^{2}\end{array}$ & $\begin{array}{l}48 \mathrm{~h} \mathrm{EE} \\
14 \mathrm{~d} \text { adaptation }\end{array}$ & $\begin{array}{l}\text { One meal }(9.3 \mathrm{MJ}) \\
\text { Five meals }(1.9 \mathrm{MJ})\end{array}$ & $\begin{array}{l}8 \cdot 42 \\
8 \cdot 37\end{array}$ & $\begin{array}{l}1 \cdot 15 \mathrm{MJ} / \mathrm{d} \\
1 \cdot 32\end{array}$ & NS \\
\hline $\begin{array}{l}\text { Verboeket-van } \\
\text { de Venne \& } \\
\text { Westerterp } \\
(1991)\end{array}$ & $\begin{array}{l}\text { Two men, } \\
\text { eleven women: } \\
18-23 \text { years } \\
\text { BMI } 21 \mathrm{~kg} / \mathrm{m}^{2}\end{array}$ & $\begin{array}{l}24 \mathrm{~h} \mathrm{EE} \dagger \\
\text { No adaptation }\end{array}$ & $\begin{array}{l}\text { Two meals }(0.7 \times \text { SMR }) \ddagger \\
\text { Seven meals }(0.2 \times \text { SMR })\end{array}$ & $\begin{array}{l}7282 \\
7834\end{array}$ & $\begin{array}{l}230 \mathrm{~kJ} / \mathrm{d} \\
259\end{array}$ & NS \\
\hline $\begin{array}{l}\text { Verboeket-van } \\
\text { de Venne \& } \\
\text { Westerterp } \\
\text { (1993) }\end{array}$ & $\begin{array}{l}\text { Fourteen women: } \\
20-58 \text { years } \\
\text { BMI } 30 \mathrm{~kg} / \mathrm{m}^{2}\end{array}$ & $\begin{array}{l}24 \mathrm{~h} \mathrm{EE} \\
\text { After } 4 \text { weeks } \\
\text { on } 4.2 \mathrm{MJ} / \mathrm{d} \text { diet }\end{array}$ & $\begin{array}{l}\text { Two meals } \\
\text { Three to five meals } \S\end{array}$ & $\begin{array}{l}7838 \\
7867\end{array}$ & $\begin{array}{l}416 \mathrm{~kJ} / \mathrm{d} \\
202\end{array}$ & NS \\
\hline \multirow[t]{2}{*}{$\begin{array}{l}\text { Verboeket-van } \\
\text { de Venne } \text { et } \\
\text { al. (1993) }\end{array}$} & $\begin{array}{l}\text { Ten men: } \\
\text { 25-61 years } \\
\text { BMI } 25 \mathrm{~kg} / \mathrm{m}^{2}\end{array}$ & $\begin{array}{l}24 \mathrm{~h} \mathrm{EE} \\
6 \mathrm{~d} \text { adaptation }\end{array}$ & $\begin{array}{l}\text { Two meals } \| \\
\text { Seven meals } \|\end{array}$ & $\begin{array}{l}9.4 \\
9.4\end{array}$ & $\begin{array}{l}0.2 \mathrm{MJ} / \mathrm{d} \\
0.2\end{array}$ & NS \\
\hline & & ADMR by $\mathrm{DLW}^{7}$ & $\begin{array}{l}\text { Two meals } \\
\text { Seven meals }\end{array}$ & $\begin{array}{l}11 \cdot 8 \\
12 \cdot 3\end{array}$ & $\begin{array}{l}0.3 \mathrm{MJ} / \mathrm{d} \\
0.5\end{array}$ & NS \\
\hline
\end{tabular}

SMR, sleeping metabolic rate; EE, energy expenditure; ADMR by DLW ${ }^{7}$, average daily metabolic rate measured over $7 \mathrm{~d}$ by doubly-labelled-water method.

* Measured twice (after 7 d and 14d) on nibbling and gorging regimen; average results presented. Also analysed by five shorter intervals.

$\dagger$ Also analysed by $3 \mathrm{~h}$ intervals.

$\ddagger$ Total daily need assessed as $1.4 \times$ SMR measured previously.

$\S$ Two meals, $1.7 \mathrm{MJ}$ lunch, $2.5 \mathrm{MJ}$ supper; three to five meals, $1.25 \mathrm{MJ}$ breakfast, $1.25 \mathrm{MJ}$ lunch, $1.77 \mathrm{MJ}$ supper with flexibility to use some lunch or supper as snacks.

$\|$ Energy intake (EI) based on $7 \mathrm{~d}$ record. Two meals, $40 \%$ EI lunch, $60 \%$ EI supper; seven meals, $100 \%$ EI divided between seven small meals and snacks between $07.30-20.30$ hours. 
These studies provide a very strong consensus that there is no effect of meal pattern on total energy expenditure. In most of the studies the group mean values for $24 \mathrm{~h}$ energy expenditure are almost identical on the different treatments. The single doubly-labelledwater study corroborates the calorimetry results.

Within the $24 \mathrm{~h}$ period several studies observed shifts in the diurnal pattern of energy expenditure in a predictable direction. For instance, Dallosso et al. (1982) reported significantly raised night-time expenditure on the gorging regimen. This was caused by ingestion of the second large meal at 19.00 hours, at the same time as the last of the much smaller nibbling meals when on the alternative treatment. The significantly raised nighttime expenditure was compensated for by a lower daytime expenditure. Similar results were reported by Verboeket-van de Venne et al. (1993) who observed the anticipated increase in energy expenditure immediately after the larger meals.

Whole-body calorimetry can also be used to obtain an integrated estimate of total TEF over a $24 \mathrm{~h}$ period. This is achieved by calculating the slope of the relationship between activity counts (measured by Doppler) and energy expenditure. The zero intercept of this line represents energy expenditure at a state of total rest. It is then assumed that the difference between this value and BMR represents TEF. In two separate studies Verboeketvan de Venne \& Westerterp (1993) and Verboeket-van de Venne et al. (1993) have performed this calculation and demonstrated that there was no significant influence of meal frequency on TEF after adjustment for the relevant time intervals.

\section{CONCLUSIONS AND PRIORITIES FOR FUTURE RESEARCH}

We conclude that there is robust evidence from several independent laboratories to refute the hypothesis that feeding frequency is a significant determinant of energetic efficiency in human subjects when assessed over $24 \mathrm{~h}$ or longer. Consequently, feeding frequency has no significant impact on the rate of weight loss during energy restriction. We further conclude that the epidemiological studies which have suggested that nibbling is associated with leanness are extremely vulnerable to methodological errors which may generate spurious relationships due to dietary under-reporting and post hoc alterations in eating patterns in response to weight gain. Although these may not totally invalidate the cross-sectional studies, they highlight the need for considerable caution in interpreting the results and point to the need for a more critical analysis in the future.

Since we conclude that feeding frequency has no discernible effect on $24 \mathrm{~h}$ energy expenditure, then any putative effects on regulation of body weight must be mediated through effects on the intake side of the energy balance equation. Aspects of this question are reviewed elsewhere in this workshop (de Castro, 1997; Gatenby, 1997), but may also require fresh experimental approaches. Future research might usefully investigate the effects of meal frequency on spontaneous food selection and on the regulation of energy intake. This should address both the immediate effects of high and low meal frequencies, and the downstream effects on later meals. One prospective study in hyperlipidaemic patients already suggests that recommendations to increase or decrease meal frequency are accompanied by concomitant changes in overall energy intake and in body weight (King \& Gibney, 1997). Interactions between meal frequency and habitual levels of physical activity might also be important. The difficulties of such research with respect to the confounding effects of under-reporting should not be underestimated.

In the field of eating disorders there is emerging interest in the potential interaction between eating frequency and the development and treatment of eating disorders. 
Cognitive behavioural therapies for bulimia stress the importance of establishing regular meal patterns, and some practitioners are recommending high snack frequencies as a means of inhibiting bingeing. There is a need for a formal appraisal of the evidence base for such interventions.

Any decisions regarding dietary advice in favour of the adoption of nibbling or gorging meal patterns should be dominated by a consideration of the effects on carbohydrate and lipid metabolism (Jenkins, 1997; Mann, 1997), rather than on energy expenditure, where a prudent analyst would probably conclude that the metabolic effects are neutral.

We are most grateful to Dr Carolyn Summerbell for providing translations of some of the cited papers.

\section{REFERENCES}

Acheson, K. J., Flatt, J.-P. \& Jéquier, E. (1982). Glycogen synthesis versus lipogenesis after a 500 gram carbohydrate meal in man. Metabolism 31, 1234-1240.

Adams, C. E. \& Morgan, K. J. (1981). Periodicity of eating: implications for human food consumption. Nutrition Research 1, 525-550.

Anderson, I. \& Rossner, S. (1996). Meal patterns in obese and normal weight men: The 'Gustaf' study. European Journal of Clinical Nutrition 50, 639-646.

Belko, A. Z. \& Barbieri, T. F. (1987). Effect of meal size and frequency on the thermic effect of food. Nutrition Research 7, 237-242.

Bellisle, F. (1995). Grignotage et distribution circadienne de la consommation alimentaire (Nibbling and circadian distribution of food consumption). Cahiers de Nutrition Dietetique 30, 387-394.

Black, A. E., Prentice, A. M., Goldberg, G. R., Jebb, S. A., Bingham, S. A., Livingstone, M. B. E. \& Coward, W. A. (1993). Measurements of total energy expenditure provide insights into the validity of dietary measurements of energy intake. Journal of the American Dietetic Association 93, 572-579.

Bortz, W. M., Wroldsen, A., Issekutz, B. \& Rodahl, K. (1966). Weight loss and frequency of feeding. New England Journal of Medicine 274, 376-379.

Charzewska, J., Kulesza, W., Brzezinska, J. \& Chwojnowska, Z. (1981). Relationship between obesity or overweight development and the frequency of meals, their distribution during the day and consumption of atherogenic food products. Zywienie Czlowieka 8, 217-227 (in Polish).

Cohn, C. \& Allweiss, M. D. (1963). Fats, rats, chickens, and men - results of feeding frequency. American Journal of Clinical Nutrition 12, 255-265.

Dallosso, H., Murgatroyd, P. R. \& James, W. P. T. (1982). Fieeding frequency and energy balance in adult males. Human Nutrition: Clinical Nutrition 36C, 25-39.

de Castro, J. (1997). Socio-cultural determinants of meal size and frequency. British Journal of Nutrition 77 , Suppl. 1, S39-S55.

Debry, G., Azouaou, R., Vassilitch, I. \& Mottaz, G. (1973). Ponderal losses in obese subjects submitted to restricted diets differing by nibbling and by lipid and carbohydrate. In Energy Balance in Man, pp. 305-310 [M. Apfelbaum, editor]. Paris: Masson.

Dreon, D. M., Frey-Hewitt, B., Ellsworth, N., Williams, P. T., Terry, E. B. \& Wood, P. D. (1988). Dietary fat : carbohydrate ratio and obesity in middle-aged men. American Joumal of Clinical Nutrition 47, 995-1000.

Edelstein, S. L., Barrett-Connor, E. L., Wingard, D. L. \& Cohn, B. A. (1992). Increased meal frequency associated with decreased cholesterol concentrations; Rancho Bernardo, CA, 1984-1987. American Journal of Clinical Nutrition 55, 664-669.

Fabry, P., Fodor, J., Hejl, Z., Braun, T. \& Zvolankova, K. (1964). The frequency of meals: its relation to overweight, hypercholesterolaemia, and decreased glucose tolerance. Lancet ii, 614-615.

Fabry, P., Hejda, S., Cerna, K., Osoncova, K., Pechor, J. \& Zvolankova, K. (1966). Effect of meal frequency in schoolchildren: changes in weight-height proportion and skinfold thickness. American Journal of Clinical Nutrition 18, 358-361.

Fabry, P. \& Tepperman, J. (1970). Meal frequency - a possible factor in human pathology. American Journal of Clinical Nutrition 23, 1059-1068.

Finkelstein, B. \& Fryer, B. A. (1971). Meal frequency and weight reduction of young women. American Joumal of Clinical Nutrition 24, 465-468.

Flatt, J.-P. (1985). Energetics of intermediary metabolism. Substrate and Energy Metabolism, pp. 58-69 [J. S. Garrow and D. Halliday, editors]. London: John Libbey. 
Garrow, J. S., Durrant, M., Blaza, S., Wilkins, D., Royston, P. \& Sunkin, S. (1981). The effect of meal frequency and protein concentration on the composition of the weight lost by obese subjects. British Journal of Nutrition $45,5-15$.

Gatenby, S. J. (1997). Eating frequency: methodological and dietary aspects. British Journal of Nutrition 77, Suppl. 1, S7-S20.

Goldberg, G. R., Black, A. E., Jebb, S. A., Cole, T. J., Murgatroyd, P. R., Coward, W. A. \& Prentice, A. M. (1991). Critical evaluation of energy intake data using fundamental principles of energy physiology. 1. Derivation of cut-off limits to identify under-recording. European Journal of Clinical Nutrition 45, $569-581$.

Heitmann, B. L. \& Lissner, L. (1995). Dietary underreporting by obese individuals - is it specific or nonspecific? British Medical Journal 311, 986-989.

Hejda, S. \& Fabry, P. (1964). Frequency of food intake in relation to some parameters of the nutritional status. Nutrition Dieta 6, 216-221.

Jenkins, D. J. A. (1997). Carbohydrate tolerance and food frequency. British Journal of Nutrition 77, Suppl. 1 , S71-S81.

Jéquier, E. (1992). Caloric balance versus nutrient balance. Energy Metabolism: Tissue Determinants and Cellular Corollaries, pp. 123-136 [J. M. Kinney and H. N. Tucker, editors]. New York: Raven Press.

Kant, A. K. (1995). Frequency of eating occasions and weight change in NHANES I Epidemiologic Follow-up Study. International Journal of Obesity 19, 468-474.

Kinabo, J. L. D. \& Durnin, J. V. G. A. (1990). Effect of meal frequency on the thermic effect of food in women. European Journal of Clinical Nutrition 44, 389-395.

King, S. M. \& Gibney, M. J. (1997). The effect of dietetic advice on incorporating altered meal frequency for hyperlipidaemic patients on low-fat diets. Proceedings of the Nutrition Society 56, 131A.

Kulesza, W. (1980). Dietary intake of obese women. Zywienie Czlowieka 7, 69-76.

LeBlanc, J., Mercier, I. \& Nadeau, A. (1993). Components of postprandial thermogenesis in relation to meal frequency in humans. Canadian Journal of Physiology and Pharmacology 71, 879-883.

Lichtman, S. W., Pisarska, K., Berman, E. R., Pestone, H., Dowling, H., Offenbacker, E., Weisser, H., Heshka S., Matthews, D. E. \& Heymsfield, S. B. (1992). Discrepancy between self-reported and actual caloric intake and exercise in obese subjects. New England Journal of Medicine 327, 1893-1898.

Livingstone, M. B. E., Prentice, A. M., Strain, J. J., Coward, W. A., Black, A. E., Barker, M. E., McKenna, P. G. \& Whitehead, R. G. (1990). Accuracy of weighed dietary records in studies of diet and health. British Medical Journal 300, 708-712.

Mann, J. (1997). Meal frequency and plasma lipids and lipoproteins. British Journal of Nutrition 77, Suppl. 1, S83-S90.

Metzner, H. L., Lamphiear, D. E., Wheeler, N. C. \& Larkin, F. A. (1977). The relationship between frequency of eating and adiposity in adult men and women in the Tecumseh Community Health Study. American Journal of Clinical Nutrition 30, 712-715.

Molnar, D. (1992). The effect of meal frequency on postprandial thermogenesis in obese children. Padiatrie Padologi 27, 177-181.

Nunes, W. T. \& Canham, J. E. (1963). The effect of varied periodicity of eating on serum lipids and carbohydrate tolerance in man. American Journal of Clinical Nutrition 12, 334-339.

Poppitt, S. D., Swann, D., Black, A. E. \& Prentice, A. M. (1995). Is under-reporting of energy intake in obese women macronutrient specific? Covert measurements in a metabolic facility. International Journal of Obesity 19, Suppl. 2, 29.

Prentice, A. M., Black, A. E., Coward, W. A., Davies, H. L., Goldberg, G. R., Murgatroyd, P. R., Ashford, J., Sawyer, M. \& Whitehead, R. G. (1986). High levels of energy expenditure in obese women. British Medical Journal 292, 983-987.

Summerbell, C. D., Moody, R. C., Shanks, J., Stock, M. J. \& Geissler, C. (1996). Relationship between feeding pattern and body mass index in 220 free-living people in four age groups. European Journal of Clinical Nutrition 50, 513-519.

Swindells, Y. E., Holmes, S. H. \& Robinson, M. F. (1968). The metabolic response of young women to changes in the frequency of meals. British Journal of Nutrition 22, 667-680.

Tai, M. M., Castillo, P. \& Pi-Sunyer, F. X. (1991). Meal size and frequency: effect on the thermic effect of food. American Journal of Clinical Nutrition 54, 783-787.

Thomas, J. A. \& Call, D. (1973). Eating between meals - a nutritional problem among teenagers? Nutrition Reviews 31, 137-139.

Verboeket-van de Venne, W. P. H. G. \& Westerterp, K. R. (1991). Influence of the feeding frequency on nutrient utilisation in man: consequences for energy metabolism. European Journal of Clinical Nutrition 45, 161169.

Verboeket-van de Venne, W. P. H. G. \& Westerterp, K. R. (1993). Frequency of feeding, weight reduction and energy metabolism. International Journal of Obesity 17, 31-36.

Verboeket-van de Venne, W. P. H. G., Westerterp, K. R. \& Kester, A. D. M. (1993). Effect of the pattern of food intake on human energy metabolism. British Journal of Nutrition 70, 103-115. 
Wolfram, G., Kirchbegner, M., Müller, H. L. \& Hollorney, S. (1987). Thermogenese des Menschen bei unterschiedlicher Malzeitenhäufigkeit (Thermogenesis in human subjects with differing meal frequencies). Annals of Nutrition and Metabolism 31, 88-97.

Young, C. M., Scanlon, S. S., Topping, C. M., Simko, V. \& Lutwak, L. (1971). Frequency of feeding, weight reduction and body composition. Journal of the American Dietetic Association 59, 466-472. 